\title{
Analysis of constraints to agricultural production in the Sudan Savanna Zone of Nigeria using multi-scale characterization.
}

\author{
A.O. OGUNGBILE ${ }^{1}$, R. TABO ${ }^{2}$, N. VAN DUIVENBOODEN ${ }^{3}$ AND S.K. DEBRAH ${ }^{4}$ \\ 1. Institute for Agricultural Research (IAR)/ABU, PMB 1044, Samaru, Nigeria \\ 2. ICRISAT, PMB 3491, Kano, Nigeria \\ 3. ICRISAT Sahelian Center, BP 12404, Niamey, Niger \\ 4. ICRISAT, B.P. 320, Bamako, Mali (Present address: International Fertilizer Development Center (IFDC) \\ B.P. 4483, Lome, Togo) \\ * Corresponding author (fax: +234-64-663492; e-mail: r.tabo@cgnet.com) \\ Received 28 May 1997; accepted 26 February 1998
}

\begin{abstract}
A multi-scale characterization approach was used to identify the major constraints to agricultural production and to characterize the major production systems in the Sudan Savanna Zone of northern Nigeria. Relative emphasis was placed on the household-level characterization to have a better understanding of the land use system, farmers' constraints and opportunities, so as to better target agricultural technologies and interventions in this vast agroecological zone. Large variations exist in agricultural management practices among villages and households in terms of access to resources, such as labour, fertilizers, livestock, farm equipment, and land. Intensive and extensive farming practices co-exist within the same villages and households. Results were also used to identify benchmark sites.
\end{abstract}

\section{Résumé}

Une approche de caractérisation multi-échelle a été utilisée pour identifier les principales contraintes à la production agricole et caracteriser les systemes de production dans la zone savanne soudanienne du nord-Nigéria. L'accent a été mis sur la caractérisation au niveau des ménages pour mieux comprendre les systèmes d'utilisation des terres, les contraintes et possibilités des paysans afin de mieux cibler les technologies et les interventions pour cette vaste zone agro-écologique. Il y a des grandes différences dans les pratiques de gestion agricole entre les villages et les exploitations, en termes d'acces aux ressources comme la main-d'oeuvre, les engrais, le bétail, les équipements agricoles, et la terre. Des pratiques de culture intensive et extensive co-existent au sein des mêmes villages et ménages. Les résultats ont également permis d'identifier des sites de référence.

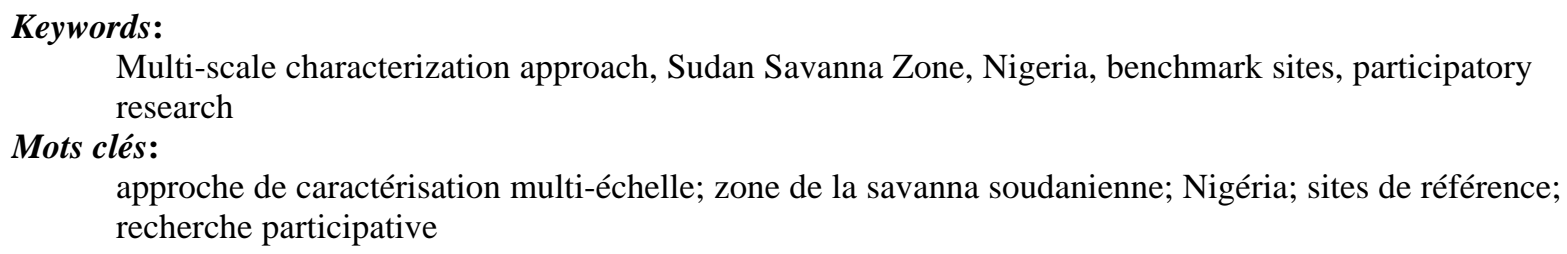

\section{Introduction}

Agricultural potential in Nigeria is unlimited with opportunities for agricultural development spanning five agroecological zones, each with its unique characteristics. The Sudan Savanna agro-ecological zone alone, extending between latitudes $9^{\circ} 30^{\prime}$ and $12^{\circ} 31^{\prime} \mathrm{N}$ and longitutes $4^{\circ}$ to $14^{\circ} 30^{\prime} \mathrm{E}$, occupies about 22.8 million hectares (Manyong et al., 1995). Its rainfall is unimodal and ranges in space and in time between 600 and $1000 \mathrm{~mm}$ per annum. The zone is characterized by a length of growing period of about 100-150 days and opportunities exist for 
the cultivation of rainfed cereals, groundnuts, cowpea, cotton, pigeonpea, irrigated rice and wheat, and vegetables. The zone includes six states, each having its own agricultural development project. Cropping systems are based on millet and sorghum, but with the increasing population densities, and the recent reduction in fertilizer subsidies, the quest for alternative, but yet productive and sustainable production systems becomes more important.

As with other agro-ecological zones, there is a large diversity in the Sudan Savanna zone in terms of biophysical (climate, land form, hydrology, etc.) and socio- economic (land and labour resources, marketing and tenure practices, etc.) parameters. As a result, agricultural technologies developed to address problems across agroecological zones have been of limited value and have not been adopted to any appreciable extent. Since the land use systems and production strategies adopted by farmers depend on the interactions between the biophysical and socioeconomic resources available to them, it is only through characterization and diagnosis at different levels of scale that a better understanding of the environment in which farmers operate and of the constraints can be obtained for accurate targeting of improved technologies and policies. Since research institutes do not have the financial nor the human capacity to investigate all combinations, a sound selection therefore needs to be made that is representative of a larger area, i.e. the benchmark sites.

The objectives of this study were to carry out a multi-scale characterization in Nigeria across states to identify constraints to production, and subsequently to select benchmark sites within the Sudan Savanna zone for further technology development and testing with farmers so as to facilitate extension of results to similar areas.

\section{Materials and methods}

A multi- scale characterization method was used (cf. Andriesse et al., 1994; Van Duivenbooden, 1997) with administrative units as unit of analysis. It telescopes down from State, via Local Government Area (LGA) and village to households. The states of Kano, Jigawa and Katsina were selected as representative of the Sudan Savanna zone in terms of rainfall amount and distribution, and vegetation. The study was carried out in three LGAs selected in each state based on annual rainfall within the last five years (longer periods were not available), representativity of the production systems and geographical position within the states. In each LGA, a survey was made in villages on a transect with a north-south axis. The villages (Figure 1) were selected on the basis of annual rainfall (19911995), geographical position in the state, accessibility, and representativity of main production systems and ethnic groups. Detailed characterization was carried out in one village selected in each LGA. In those villages, a Participatory Rural Appraisal survey was conducted in September and October 1996, and activities of households (selected on the basis of interviews) were monitored. Additional interviews with the household heads were held to determine their farming practices and resource endowments.

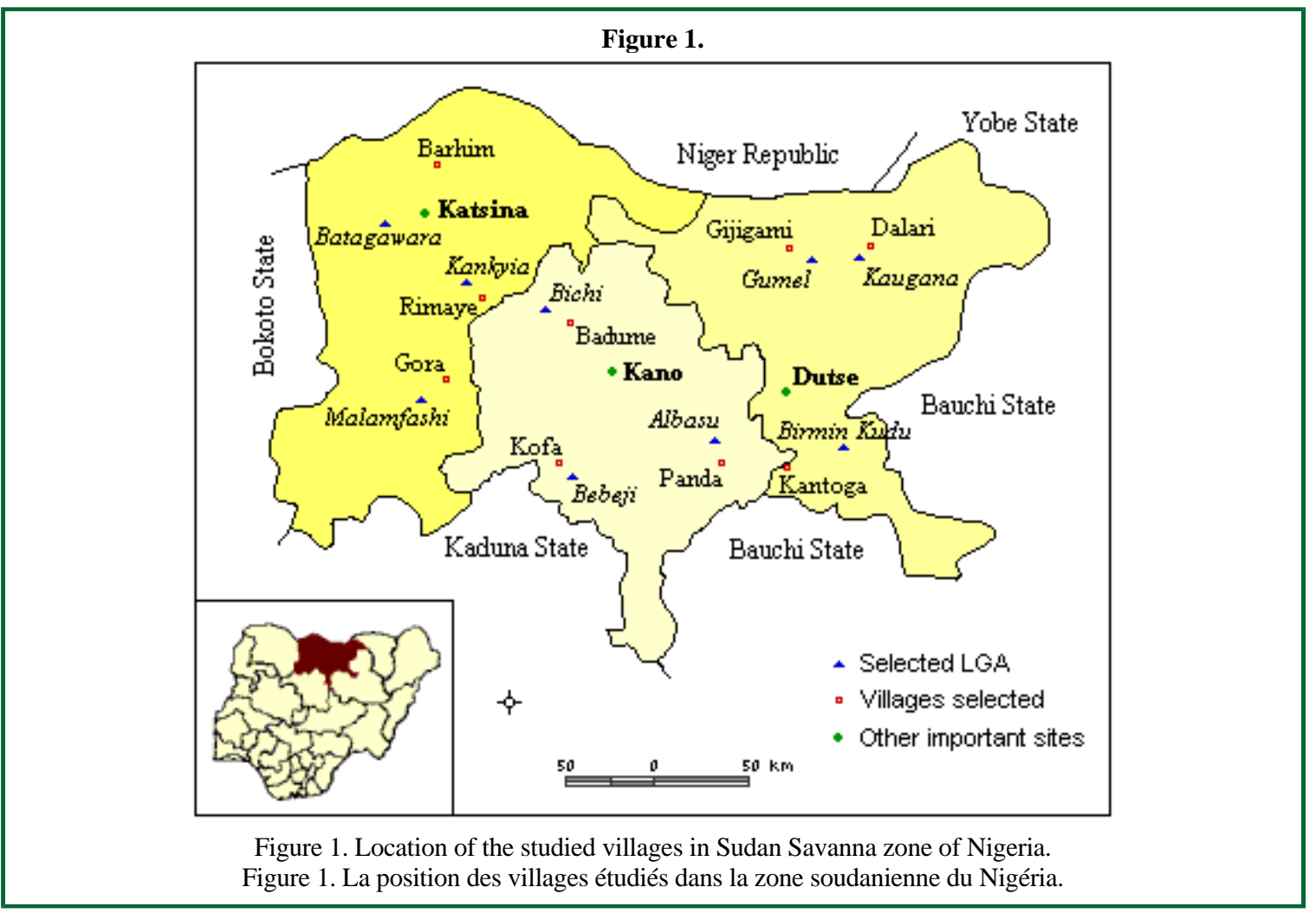


Although the Sudan Savanna Zone is often subdivided in Nigeria into the wet and the dry sub-zone, in this study, three zones were distinguished on the basis of average annual rainfall:

i. the southern zone from $11^{\circ} 30^{\prime}$ to $11^{\circ} 55^{\prime}$ with $951 \mathrm{~mm}$;

ii. the middle zone from $12^{\circ} 12^{\prime}$ to $12^{\circ} 19^{\prime}$ with $777 \mathrm{~mm}$; and

iii. the northern zone from $12^{\circ} 34^{\prime}$ to $12^{\circ} 58^{\prime}$ with $512 \mathrm{~mm}$ (Table 1 ).

Table 1. Location and selected bio-physical details of the nine villages in Nigeria.

Tableau 1. La position et quelques details bio-physiques des neuf villages au Nigéria.

\begin{tabular}{|c|c|c|c|c|c|c|c|c|}
\hline \multirow[t]{2}{*}{ State } & \multirow[t]{2}{*}{$\begin{array}{l}\text { No. } \\
\text { LGAs }\end{array}$} & \multirow[t]{2}{*}{$\begin{array}{l}\text { Selected } \\
\text { LGA }\end{array}$} & \multirow[t]{2}{*}{$\begin{array}{l}\text { Village } \\
\text { Name }\end{array}$} & \multirow[t]{2}{*}{$\begin{array}{l}\text { sub- } \\
\text { zone }\end{array}$} & \multicolumn{2}{|c|}{$\begin{array}{c}\text { Village } \\
\text { coordinates }\end{array}$} & \multirow[t]{2}{*}{$\begin{array}{l}\text { Main soil } \\
\text { type }\end{array}$} & \multirow[t]{2}{*}{$\begin{array}{r}\text { Average rainfal } \\
(\mathbf{m m})\end{array}$} \\
\hline & & & & & Lat. & Long. & & \\
\hline \multirow[t]{3}{*}{ Kano } & \multirow[t]{3}{*}{34} & Bebeji & Kofa & South & $11^{\circ} 34^{\prime}$ & $8^{\circ} 17^{\prime}$ & Loamy & 957 \\
\hline & & Albasu & Panda & South & $11^{\circ} 31^{\prime}$ & $9^{\circ} 04^{\prime}$ & Loamy & 787 \\
\hline & & Bichi & Badume & Middle & $12^{\circ} 12^{\prime}$ & $8^{\circ} 19^{\prime}$ & Sandy & 675 \\
\hline \multirow[t]{3}{*}{ Jigawa } & \multirow[t]{3}{*}{21} & B/Kudu & Kantoga & South & $11^{\circ} 30^{\prime}$ & $9^{\circ} 23^{\prime}$ & Sandy loam & 1011 \\
\hline & & Kaugama & Dalari & North & $12^{\circ} 36^{\prime}$ & $9^{\circ} 48^{\prime}$ & Sandy & 462 \\
\hline & & Gumel & Gijigami & North & $12^{\circ} 34^{\prime}$ & $9^{\circ} 25^{\prime}$ & Sandy & 612 \\
\hline \multirow[t]{3}{*}{ Katsina } & \multirow[t]{3}{*}{21} & Malumfashi & Gora & South & $11^{\circ} 55^{\prime}$ & $7^{\circ} 43^{\prime}$ & Loamy & 1050 \\
\hline & & Kankyia & Rimaye & Middle & $12^{\circ} 19^{\prime}$ & $7^{\circ} 54^{\prime}$ & Loamy & 879 \\
\hline & & Batagarawa & Barhim & North & $12^{\circ} 58^{\prime}$ & $7^{\circ} 41^{\prime}$ & Sandy & 461 \\
\hline
\end{tabular}

\section{Results and discussion}

\section{Rainfall}

At the scale of agro-ecological zone, the mean annual rainfall at the sites for the 1996 cropping season varied between $531 \mathrm{~mm}$ in the north and $920 \mathrm{~mm}$ in the southern parts of the zone. The increase in precipitation was almost linearly with the change in latitude as one moves southwards (Kowal \& Kassam, 1978). The length of the growing period is shorter in the North mainly caused by an earlier end of rain. Compared with the average values in Table 1 , this indicates a large interannual variability. Rainfall variability at lower levels was not obtained.

\section{Soils}

The main soil types found in this part of the Sudan Savanna zone are classified as Entisols, Inceptisols and Alfisols. They are young immature well-drained soils formed of parent materials rich in quartz and crystalline rocks of basement complex and sedimentary deposits (Enewezor et al., 1990). A common feature of these soils is their low organic content, cation exchange capacity, and nutrient content, especially nitrogen and phosphorus. At the village level, the presence of hydromophic soils occurring in inland valleys, in addition to the upland soils increases the possibilities for diversified production systems. The ethno-soil classification, however, uses only soil texture to distinguish three classes (Table 1 ). This may bring us a little closer to targeting technologies with respect to water use, as demonstrated in the Sudan Savanna zone of Mali (Kanté \& Defoer, 1994).

\section{Land use}

At the level of the state, land use comprises both cereal-based cropping and ruminant-based livestock activities with considerable variability in most characteristics among LGAs and villages at lower scale levels (Tables $\underline{2}$ and $\underline{3}$ ). Averaged over the states, farm sizes increase as one moves from the south to the north, i.e. 3.9, 4.6 and 6.5 ha in the southern, middle and northern zone, respectively. These farm sizes exceed the average size of 1.2 ha in Borno state in the same agro-ecological zone (Bdliya, 1991). They are however smaller than the farm sizes in the past as indicated by Mortimore (1993a), who reported that the expansion of cultivated areas has reached its peak several decades ago. 
Table 2. Selected characteristics of the nine villages in Sudan Savanna zone of Nigeria.

Tableau 2. Quelques caractéristiques des neuf villages dans la zone soudanienne du Nigéria.

\begin{tabular}{|c|c|c|c|c|c|c|c|c|c|c|}
\hline \multirow{2}{*}{$\begin{array}{l}\text { State } \\
\text { Village }\end{array}$} & \multicolumn{3}{|c|}{ Kano } & \multicolumn{3}{|c|}{ Jigawa } & \multicolumn{3}{|c|}{ Katsina } & \multirow[b]{3}{*}{ Mean } \\
\hline & Kofa & Panda & Badume & Kantoga & Dalari & Gijigami & Gora & Rimaye & Barhim & \\
\hline Subzone & South & South & Middle & South & North & North & South & Middle & North & \\
\hline Village population & 1020 & 2260 & 1446 & 1700 & 1000 & 680 & 2000 & 900 & 900 & 1323 \\
\hline Households selected & 10 & 16 & 11 & 19 & 19 & 16 & 19 & 19 & 15 & 16 \\
\hline Household size (-) & 12 & 13 & 11 & 13 & 15 & 13 & 16 & 16 & 12 & 13 \\
\hline Working members/fam. & 4 & 4 & 4 & 4 & 5 & 4 & 7 & 6 & 4 & 5 \\
\hline Farm size (ha) & 4.0 & 4.6 & 3.7 & 3.3 & 8.5 & 4.7 & 3.8 & 5.5 & 6.2 & 4.7 \\
\hline No. of fields & 4 & 3 & 3 & 4 & 4 & 4 & 4 & 4 & 3 & 3.7 \\
\hline Household member $\left(\mathrm{ha}^{-1}\right)$ & 3.0 & 2.8 & 3.0 & 2.1 & 1.7 & 2.7 & 4.2 & 2.2 & 4.0 & 2.9 \\
\hline Working members $\left(\mathrm{ha}^{-1}\right.$ ) & 1.0 & 0.9 & 1.1 & 1.2 & 0.6 & 0.9 & 1.8 & 1.1 & 0.6 & 1.0 \\
\hline Fallow & None & None & None & None & Some & Some & None & Some & None & \\
\hline NPK $\left(\mathrm{kg} \mathrm{ha}^{-1}\right)$ & 68.1 & 77.3 & 95.0 & 62.4 & 63.0 & 59.8 & 70.6 & 114.0 & 58.5 & 74.3 \\
\hline Manure $\left(\mathrm{kg} \mathrm{ha}^{-1}\right)$ & 648 & 728 & 644 & 326 & 528 & 695 & 730 & 396 & 124 & 535.4 \\
\hline Cattle & 3 & 4 & 4 & 4 & 5 & 4 & 3 & 3 & 2 & 3.6 \\
\hline Goat & 5 & 7 & 4 & 5 & 6 & 4 & 4 & 4 & 3 & 4.7 \\
\hline Sheep & 4 & 5 & 6 & 5 & 4 & 3 & 6 & 5 & 5 & 4.8 \\
\hline Chicken & 13 & 16 & 15 & 14 & 12 & 14 & 10 & 12 & 10 & 12.9 \\
\hline
\end{tabular}

In Kano state, land use intensity is high in Kofa and Badume, where virtually no grazing land is available for livestock during the rainy season. Badume is only about $36 \mathrm{~km}$ north-east of Kano city, in what is called the Kano closed- settled zone (Mortimore, 1993b). Panda is further away (73 km) from any major city with more land available for farming, resulting in the highest average farm size in this state (Table $\underline{2}$ ). In Jigawa state, the average farm size (5.5 ha) is the largest of the three states, and to some extent fallowing still exists, lasting 2-3 years (Table 2). In addition, there are communal grazing areas and woodlot plantations in the selected villages. In Katsina State, continuous cropping is very common in Gora and Barhim. Farming in Gora is highly intensified because of the former Funtua enclaved Agricultural Development Project, one of the first agricultural programs started in Nigeria. Barhim is located about $6 \mathrm{~km}$ south-west of Katsina city, and thus being under direct influence of markets and business of the state capital. Here, farm expansion is difficult. In Rimaye, a rural farming community not close to any major town, some fallowing can still be practiced.

\section{Cropping systems}

Cropping systems in the three states are mainly based on sorghum. On the North-South axis, the importance of sorghum increases and that of millet decreases, while groundnut and cowpea are the major cash crops regardless of the geographical position. Sole crops are predominant in the middle and northern zones, but variability in surface cultivated at both state and village level is considerable (Table $\underline{3}$ ). For sorghum, for instance, 33\% of the area is cultivated with one other crop, $11 \%$ with two crops, and $7 \%$ as a sole crop. For millet, these values are 17, 3, and $4 \%$, respectively. This implies a shift towards sorghum as compared to the 70's when the systems were dominated by millet (Gosden quoted by Elemo, 1989). Maize and rice cover together 5\% and their cultivation has declined drastically in the southern part due to the high prices of fertilizers. The last group comprises other subsidiary crops, like sesame, vegetables and peppers, grown in a variety of intercrops, and covering 14\% (Table $\underline{3}$ ).

The most important two-crop-system observed include sorghum/millet, sorghum/groundnut, sorghum/cowpea, millet/groundnut and millet/cowpea. For the three- crop- system, these are sorghum/millet/cowpea, and sorghum/groundnut/cowpea (Table $\underline{3}$ ). Three-crop-systems and other patterns were most common in the villages in the southern sub-zone with higher rainfall and more fertile loamy soils. Other important enterprises specific to some locations include sorghum/cotton found in Gora and Rimaye in Katsina state. 


\section{Labour force}

At the village and household level, labour force is considered one of the most limiting factors by the resource poor farmers. The actual labour force for agriculture is currently about $36 \%$ of the household size (Table 2). This is lower than before due to disappearance of the 'gandu' practice, i.e. where more than one household head join together to farm and eat. Except in Gijigami village, where the majority of inhabitants are of the Kanuri tribe, female adults of child-bearing age do not work on the field, but they process the harvested produce brought home from the field. Hired labour costs constituted 20 to $30 \%$ of total production costs while total labour costs exceeded $70 \%$ of the production cost. The cost of family labour was imputed since family labour had opportunity costs in non-farm activities in the area, especially in those villages close to a state capital.

Table 3. Cropping systems in the nine villages in the Sudan Savanna zone of Nigeria in 1996.

Tableau 3. Les systèmes de culture dans les neuf villages dans la zone soudanienne du Nigéria en 1996.

\begin{tabular}{|c|c|c|c|c|c|c|c|c|c|}
\hline \multirow{2}{*}{ Type } & \multicolumn{3}{|l|}{ Kano } & \multicolumn{3}{|l|}{ Jigawa } & \multicolumn{3}{|c|}{ Katsina } \\
\hline & Kofa & Panda & Badume & Kantoga & Dalari & Gijigami & Gora & Rimaye & Barhim \\
\hline \multicolumn{10}{|l|}{ Sole } \\
\hline Sorghum & 8 & 8 & 9 & 7 & 6 & 2 & 8 & 10 & 7 \\
\hline Millet & 0 & 3 & 3 & 0 & 5 & 10 & 0 & 10 & 3 \\
\hline Gnt & 0 & 0 & 0 & 0 & 4 & 0 & 0 & 0 & 0 \\
\hline Maize & 2 & 1 & 12 & - & - & - & 5 & - & - \\
\hline Cowpea & 1 & - & - & - & 5 & 9 & 6 & - & 3 \\
\hline Rice & 9 & 3 & - & 2 & - & - & 9 & - & - \\
\hline sub-total & 20 & 15 & 24 & 9 & 20 & 21 & 28 & 20 & 13 \\
\hline
\end{tabular}

2-Crops Mixture

\begin{tabular}{|c|c|c|c|c|c|c|c|c|c|}
\hline Sor/mil & 14 & 5 & 9 & 7 & 6 & 7 & 11 & - & 7 \\
\hline Sor/gnt & 9 & 14 & 17 & 9 & 5 & - & 12 & 15 & 10 \\
\hline Sor/cow & 12 & 12 & 16 & 11 & 9 & 13 & 14 & 15 & 9 \\
\hline Sor/cot & - & - & - & - & - & - & 9 & 11 & - \\
\hline Sor/ses & - & - & - & 2 & 2 & 7 & - & - & - \\
\hline Mil/gnt & 10 & 4 & 4 & 8 & 7 & - & 7 & 11 & 16 \\
\hline $\mathrm{Mil} / \mathrm{cow}$ & 8 & 3 & 5 & 8 & 9 & 9 & 6 & 11 & 11 \\
\hline $\mathrm{Mil} / \mathrm{cot}$ & - & - & 2 & 5 & - & - & - & 9 & - \\
\hline Gnt/cow & - & 3 & 13 & 3 & 3 & 9 & - & - & - \\
\hline sub-total & 53 & 41 & 66 & 53 & 41 & 45 & 56 & 72 & 53 \\
\hline \multicolumn{10}{|c|}{ 3-Crops Mixture } \\
\hline Sor/mil/gnt & 11 & 9 & 10 & 8 & - & 6 & - & - & 7 \\
\hline Sor/mil/cow & 7 & 8 & - & 12 & 9 & 13 & - & - & 7 \\
\hline Mil/gnt/cow & - & 10 & - & 8 & 3 & - & - & - & - \\
\hline sub-total & 18 & 27 & 10 & 28 & 12 & 19 & 0 & 0 & 14 \\
\hline Others & 9 & 17 & 0 & 10 & 27 & 15 & 16 & 8 & 20 \\
\hline Total & 100 & 100 & 100 & 100 & 100 & 100 & 100 & 100 & 100 \\
\hline
\end{tabular}

Sor $=$ sorghum $;$ mil = millet cow $=$ cowpea $;$ gnt $=$ groundnut $; \cot =$ cotton $;$ ses $=$ sesame .

\section{Animal husbandry}

At the LGA level, animal traction is most widely practiced in the northern villages of Dalari, Gijigami and Barhim, followed by Badume and Rimaye in the middle zone. It is the least practiced in Kofa and Kantoga in the South. This pattern coincides with the reversed pattern in actual labour force, i.e. on average 0.7 working member ha $^{-1}$ for the North compared to 1.1 for the middle and 1.2 for the South.

At the household level, sales of livestock products are very important as they bring in additional cash required for 
farming activities and domestic obligations. Every household keeps a varying herd of cattle, sheep and goats, and chicken, for the supply of animal power, manure and cash (Table 2). Cattle includes at least two bulls, required for animal traction, while donkeys are kept mainly for transportation. Due to the low pasture availability in most of the agro- ecological zone, there is usually a great demand for animal feed, especially during the dry season. Crop residues are the principal source for this, so that in addition to grains also stover may bring in cash.

\section{Fertilization}

Due to the absence of fallow, both chemical fertilizer and organic manure are used to maintain and improve soil fertility. The high cost and scarcity of fertilizers owing to poor distribution systems in recent years have forced farmers to use more animal manure, which is now applied at an average rate of about $535 \mathrm{~kg} \mathrm{ha}^{-1}$. Farmers prepare their manure in the compounds on the basis of droppings from ruminants and poultry, and crop residues. Because the quantity of manure produced by farmers is usually insufficient to cover the whole farm in any given year, it is only applied to specific spots in the field with each field receiving manure every two to three years.

The most popular chemical fertilizer is the compound NPK (20:10:10), but the amount of fertilizers applied is limited. An average household obtains a total of 150 to $250 \mathrm{~kg}$ of this NPK, which is applied at an average rate of $74 \mathrm{~kg} \mathrm{ha}^{-1}$ (Table 2). Applying average N, P, and K contents of manure of 1.27, 0.28 and $1.30 \mathrm{~g} \mathrm{~kg}^{-1}$ on DM basis, respectively (Van Duivenbooden, 1992), together with the chemical fertilizer, the total external nutrient inputs amount to $21.6,8.9$, and $14.4 \mathrm{~kg} \mathrm{ha}^{-1}$ for $\mathrm{N}, \mathrm{P}$ and $\mathrm{K}$, respectively. Assuming average nutrient uptakes requirements and fertilizer efficiencies (Van Duivenbooden et al., 1996), these inputs should be sufficient on poor soils for a millet yield of about $250-300 \mathrm{~kg} \mathrm{ha}^{-1}$ and for sorghum of $250-350 \mathrm{~kg} \mathrm{ha}^{-1}$. Since currently yields of about 500-700 $\mathrm{kg} \mathrm{ha}^{-1}$ are obtained, this implies that in most cases soil nutrient mining occurs in all villages.

\section{Financial returns}

Financial returns per hectare for crop mixtures were higher than those for sole crops (Table 4 ). This partially explains why farmers grow crops in mixtures. The average gross margins over the three states was $9347 \mathrm{Naira}^{-1}$ for sole crops. For the 2-crops and 3 -crops mixtures, returns were larger: 37 and 59\%, respectively. This indicates clearly the importance of mixed production systems in this zone.

Table 4. Production costs and returns $\left(\right.$ Naira $^{-1}{ }^{-1}$ ) for different types of cropping systems in Kano, Jigawa and Katsina states, Nigeria.

Tableau 4. Les couts de production et les revenues $\left(\mathrm{Naira} \mathrm{ha}^{-1}\right)$ pour les differents types des systèmes de culture dans les états de Kano, Jigawa et Katsina, Nigéria.

\begin{tabular}{|c|c|c|c|c|c|c|c|c|c|c|}
\hline \multirow{2}{*}{$\begin{array}{l}\text { Types of } \\
\text { systems }\end{array}$} & \multicolumn{3}{|l|}{ Kano } & \multicolumn{3}{|l|}{ Jigawa } & \multicolumn{3}{|c|}{ Katsina } & \multirow{2}{*}{$\begin{array}{c}\text { Average net } \\
\text { revenue ( } 3 \text { states) }\end{array}$} \\
\hline & $\begin{array}{l}\text { Total } \\
\text { cost }\end{array}$ & $\begin{array}{c}\text { Total } \\
\text { revenue }\end{array}$ & $\begin{array}{c}\text { Net } \\
\text { revenue }\end{array}$ & $\begin{array}{c}\text { Total } \\
\text { cost }\end{array}$ & $\begin{array}{c}\text { Total } \\
\text { revenue }\end{array}$ & $\begin{array}{c}\text { Net } \\
\text { revenue }\end{array}$ & $\begin{array}{l}\text { Total } \\
\text { cost }\end{array}$ & $\begin{array}{c}\text { Total } \\
\text { revenue }\end{array}$ & $\begin{array}{c}\text { Net } \\
\text { revenue }\end{array}$ & \\
\hline Sole crop & 6216 & 18100 & 11884 & 5539 & 14000 & 8461 & 6050 & 13750 & 7700 & 9347 \\
\hline $\begin{array}{l}\text { 2-crops } \\
\text { mixture }\end{array}$ & 7287 & 22717 & 15430 & 6572 & 17867 & 11295 & 6721 & 18420 & 11699 & 12808 \\
\hline $\begin{array}{l}\text { 3-crops } \\
\text { mixture }\end{array}$ & 7089 & 26933 & 19844 & 6918 & 17300 & 10382 & 6388 & 20700 & 14312 & 14846 \\
\hline
\end{tabular}

US\$ $1=79$ NAIRA

\section{Constraints}

On the basis of these results and additional (non-published) information, Table $\underline{5}$ has been derived. It clearly shows that constraints occur at each level of the distinguished scales. Although not made explicit in the table, differences occur between states. This implies that technologies and interventions should address different scales and spatial variability. As a consequence, for monitoring impact of interventions these scales should all be considered.

\section{Selection of benchmark sites}

On the basis of these results, the following characteristics were considered as determinant for the selection of the benchmark sites: rainfall, distance to town, farm size, cropping system, and logistic reasons. Although nine villages were surveyed in the three states, the three benchmark sites being recommended are all located in Kano state, mainly for logistics reasons, while still all characteristics of the Sudan Savanna zone can be found in these three sites. The selected sites are Kofa, Gargai and Badume. It is, however, recognized that all variability cannot be captured (e.g. soil type) in this selection. The constraints identified at each level need to be taken into account when making recommendations to policy makers and farmers on the basis of research results from these benchmark sites. 
The Kofa benchmark site represents the wettest part of the Sudan zone with an annual rainfall of $889 \mathrm{~mm}$ and is within the Bebeji LGA. It is about $80 \mathrm{~km}$ from Kano city and $6 \mathrm{~km}$ off the Kano-Zaria road. Although it is densely populated it has no village market. It has little room for farm expansion of the sorghum-based system. Cultivation is mainly manually done, with animal traction being virtually absent.

The Gargai benchmark site, in the same LGA, has an average annual rainfall of $800 \mathrm{~mm}$. It is about $66 \mathrm{~km}$ from Kano city, and although closer to cities than Kofa, it is less densely populated, leaving some room for farm expansion. It is accessible with good road and is very close to a relatively bigger town, Tiga and its market. Its proximity to the Tiga dam allows farmers to practice dry season farming using irrigation water. The cropping system is mainly sorghum based with some use of animal traction.

The Badume site, in the Bichi LGA, lies between the dry northern and wet southern parts of Kano state. It has an annual rainfall of about $700 \mathrm{~mm}$. The main road linking Kano state (through Katsina state) to Niger republic passes through this village. The site is about $40 \mathrm{~km}$ north of Kano city, and represents mainly the millet-based production systems, and secondly the sorghum-based ones. Groundnut production is also very important and trading is a major non-farm occupation.

\begin{tabular}{|c|c|c|c|c|c|}
\hline Identifier & State & LGA & Village & Household & Production system \\
\hline Infrastructure & $\begin{array}{l}\text { Investment in paved } \\
\text { roads only }\end{array}$ & $\begin{array}{l}\text { Quantity and } \\
\text { quality of } \\
\text { laterite roads }\end{array}$ & Accessibility & $\begin{array}{l}\text { Means of transport (donkeys } \\
\text { and ox-charts) }\end{array}$ & $\begin{array}{l}\text { Labour which could be } \\
\text { used for other purposes }\end{array}$ \\
\hline Population & $\begin{array}{l}\text { Rapid population } \\
\text { growth and } \\
\text { urbanization }\end{array}$ & $\begin{array}{l}\text { Land scarcity } \\
\text { around cities }\end{array}$ & $\begin{array}{l}\text { Land tenure: } \\
\text { fragmentation of land due } \\
\text { to inheritance; lack of } \\
\text { grazing and fallow land }\end{array}$ & $\begin{array}{l}\text { Land far from homestead; } \\
\text { time requirements for } \\
\text { walking; number of animals } \\
\text { that can be kept; no space for } \\
\text { extension }\end{array}$ & $\begin{array}{l}\text { Fallow and manure } \\
\text { availability required for } \\
\text { soil fertility restoration; } \\
\text { soil mining; overgrazing }\end{array}$ \\
\hline \multirow[t]{2}{*}{ Physical environment } & Low soil fertility & $\begin{array}{l}\text { Low soil } \\
\text { fertility }\end{array}$ & $\begin{array}{l}\text { Low soil fertility; } \\
\text { Lack of subsidized } \\
\text { fertilizer }\end{array}$ & $\begin{array}{l}\text { Lack of financial means to } \\
\text { buy fertilizer }\end{array}$ & $\begin{array}{l}\text { Low soil nutrient } \\
\text { availability }\end{array}$ \\
\hline & $\begin{array}{l}\text { Low and erratic } \\
\text { rainfall }\end{array}$ & $\begin{array}{l}\text { Low and erratic } \\
\text { rainfall }\end{array}$ & $\begin{array}{l}\text { Lack of water supply (dry } \\
\text { season) }\end{array}$ & $\begin{array}{l}\text { Drinking water for humans } \\
\text { and animals }\end{array}$ & Droughts \\
\hline Inputs & $\begin{array}{l}\text { Poor distribution } \\
\text { system of subsidized } \\
\text { fertilizer and other } \\
\text { inputs }\end{array}$ & $\begin{array}{l}\text { Service centres } \\
\text { do not have the } \\
\text { required inputs; }\end{array}$ & $\begin{array}{l}\text { Lack of inputs and } \\
\text { credits }\end{array}$ & $\begin{array}{l}\text { Lack of financial means to } \\
\text { buy improved seeds, etc. }\end{array}$ & Low yield potentials \\
\hline Credit/extension/services & $\begin{array}{l}\text { Poor credit, } \\
\text { extension and } \\
\text { insurance services }\end{array}$ & $\begin{array}{l}\text { Ineffective } \\
\text { extension } \\
\text { service } \\
\text { Degraded } \\
\text { tractor-hiring } \\
\text { services }\end{array}$ & $\begin{array}{l}\text { Absence of cooperations/ } \\
\text { farmer's organization } \\
\text { Lack of traction power }\end{array}$ & $\begin{array}{l}\text { Limited access to extension } \\
\text { knowledge } \\
\text { Labour availability in June- } \\
\text { July; inadequate farm tools }\end{array}$ & $\begin{array}{l}\text { Lack of improved } \\
\text { technologies } \\
\text { Weeds; higher labour } \\
\text { requirements }\end{array}$ \\
\hline Marketing & $\begin{array}{l}\text { Poor distribution } \\
\text { system }\end{array}$ & $\begin{array}{l}\text { Absence of } \\
\text { agro-industry }\end{array}$ & $\begin{array}{l}\text { Lack of processing and } \\
\text { preservation facilities; } \\
\text { Absence of village } \\
\text { markets }\end{array}$ & Possibilities to raise money & $\begin{array}{l}\text { Reduced cash crop } \\
\text { cultivation }\end{array}$ \\
\hline Biological constraints & - & - & - & - & $\begin{array}{l}\text { Parasitic weeds, insects } \\
\text { and diseases (e.g. downy } \\
\text { mildew) }\end{array}$ \\
\hline
\end{tabular}

\section{Conclusions}

Three benchmark sites, Kofa, Gargai and Badume were selected in Kano state in northern Nigeria using a multiscale characterization method and on the basis of five criteria, i.e. rainfall, distance to town, farm size, cropping system and accessibility. It is recognized that all variability cannot be captured (e.g. soil type), but with this multiscale approach constraints and opportunities at each scale level were better identified. This will help in better formulation of recommendations for (agricultural) development and targeting of technologies and interventions to specific environments, based on results related to predominantly mixed production systems from those benchmark sites. 


\section{References}

Andriesse, W., L.O. Fresco, N. van Duivenbooden \& P.N. Windmeijer, 1994.

Multi-scale characterization of inland valley agro-ecosystems in West Africa. Netherlands Journal of Agricultural Science 42: 159-179.

Bdliya, H.H., 1991.

Complementary land evaluation for small-scale farming in northern Nigeria.

Journal of Environmental Management 33: 105-116.

Elemo, K.A., 1989.

Pearl millet under small-scale traditional farming systems in Nigeria.

In: L.K. Fussell \& J. Werder (Eds), Proceedings of the regional pearl millet improvement workshop 15-19

August 1988, IAR, Samaru, Nigeria. ICRISAT Sahelian Center, Niamey, Niger, pp. 62-67.

Enewezor, W.O., E.J. Udo, K.A. Ayotade, J.A. Adepetu \& V.O. Chude. 1990.

A review of soil and fertilizer use research in Nigeria.

Federal Ministry of Agriculture and Natural resources, Lagos, pp. 241-279.

Kanté, S. \& T. Defoer, 1994.

Classification et gestion paysanne des terres en milieu Minianka. Rapport de recherche. Equipe Systèmes de Production et Gestion de Ressources Naturelles (ESPGRN) Document 94/24.

Institut d'Economie Rurale (IER), Sikasso, 33 pp.

Kowal, J.M. \& A.W. Kassam, 1978.

Agricultural ecology of savanna: a study of West Africa.

Clarendon Press, Oxford, 403 pp.

Manyong, V.M., J. Smith, G.K. Weber, S.S. Jagtap \& B. Oyewole, 1995.

Macro-characterization of agricultural systems in West Africa: An overview.

Resource and Crop Management Research Monograph No. 21. International Institute of Tropical

Agriculture (IITA), Ibadan, $66 \mathrm{pp}$.

Mortimore, M.J., 1993a.

Land transformation under agricultural intensification in northern Nigeria.

In: C.L. Jolly, \& B. Torrey (Eds), Population and land use in developing countries. National Academy Press, Washington D C, USA, pp 42-69.

Mortimore, M.J., 1993b.

The intensification of peri-urban agriculture: the Kano-close settled zone, 1964-1986.

In: B.L. Turner, R.W. Kates, \& G. Hyden (Eds), Population growth and agricultural change in Africa. University Press of Florida, Gainesville, Florida, USA, pp 356-400.

Van Duivenbooden, N., 1992.

Sustainability in terms of nutrient elements with special reference to West Africa.

Report 160, DLO-Centrum for Agrobiologisch Onderzoek (CABO-DLO), Wageningen, 278 pp.

Van Duivenbooden, N., 1997.

Exploiting multi-scale variability of land use systems to improve natural resource management in the Sudano-Sahelian zone of West Africa (musclus), Methodology and work plan.

Integrated Systems Project Report Series No. 1. International Crops Research Institute for the Semi-Arid Tropics (ICRISAT), Patancheru, 40 pp.

Van Duivenbooden, N., C.T. De Wit \& H. Van Keulen, 1996.

Nitrogen, phosphorus and potassium relations in five major cereals reviewed in respect to fertilizer recommendations using simulation modelling.

Fertilizer Research 44: 37-49.

\section{Acknowledgements}

This paper is a part of the work of the principal author during his assignment at ICRISAT-Kano as a visiting scientist. The authors want to thank the farmers in the study zone for their full cooperation. This article has been submitted as ICRISAT journal article JA 2083.

(C) NJAS 590, 1998 - Comments to: J.J.Neetson@AB.DLO.NL 